\title{
POLA PEMBAGIAN PERAN UTOH PEURAHO DALAM PEMBUATAN KAPAL NELAYAN DI LHOKSUEMAWE, ACEH
}

\author{
Wina Azzahra, Abdullah Akhyar Nasution \\ Program Studi Antropologi \\ Fakultas Ilmu Sosial dan Politik Universitas Malikussaleh \\ Aceh-Indonesia \\ Korespondensi: Winaazzahra0411@gmail.com
}

\begin{abstract}
Abstrak: Tulisan ini ingin melihat lebih jauh bagaimana pola pembagian peran Utoh Peuraho di Lhokseumawe dalam dinamika perubahan lingkungan alam, dan kondisi sosial,ekonomi, politik dan budaya dan hubungannya dengan situasi industri kapal modern.dengan menggunakan pendekatan etnografi penulis ingin menunjukkan bahwa pembagian peran utoh peuraho sangat berkaitan dengan ketersediaan bahan baku serta proses komunikasi yang dibangun oleh pemodal. Hasil penelitian menunjukkan bahwa Utoeh Peuraho merupakan salah satu profesi yang masih sangat dibutuhkan di tengah masyarakat pesisir di Lhokseumawe. Pola pembagian peran utoh peuraho terbentuk saling berkaitan satu dengan lainnya. Dengan status kedudukan tersebut terbagi menjadi tiga, yaitu : toke (pemilik kapal), kepala utoh (kepala tukang), dan utoh peuraho (awak pembuat kapal). Fungsi dari peran yang dimiliki oleh toke, kepala utoh, dan utoh peuraho berbeda-beda dan saling kerterkaitan satu sama lainnya. Dimana toke merupakan yang menyediakan modal dalam pembuatan kapal. Kepala utoh merupakan seseorang yang mendesain kapal dan mengatur pekerjaan utoh peuraho. Sedangkan utoh peuraho merupakan seseorang yang menerima perintah dari kepala utoh pada pembuatan kapal
\end{abstract}

Kata Kunci: Pola Pembagian Peran, Utoh Peuraho, Kapal Nelayan, Lhokseumawe 
Aceh Anthropological Journal, Vol. 3, No. 2, hlm: 190-201, Oktober 2019

\section{A. Pendahuluan}

Sebagai negara kepulauan terbesar di dunia, Indonesia memiliki 17.000 pulau dengan luas garis pantai sebesar $86.700 \mathrm{~km} 2$ dengan potensi terumbu karang, serta $24.300 \mathrm{~km} 2$ adalah wilayah potensi tumbuhan mangrove. Konvensi Hukum Laut Internasional pada tahun 1983 menetapkan sebuah konsep Zona Ekonomi Eksklusif (ZEE) bagi negara-negara kepulauan untuk memiliki hal dalam pengelolaan wilayah ZEE seluas 200 mil laut yang diukur dari garis dasar. Kota Lhokseumawe memiliki wilayah yang bersinggungan langsung dengan laut baik berupa pantai maupun tebing karangnya sehingga potensi dan sumber daya alam yang menjadi karakteristik Lhokseumawe adalah pantai. Keadaan topografi Lhokseumawe memiliki ketinggian 125 meter di atas permukaan laut (Annisha, 2017).

Secara letak geografisnya Kota Lhokseumawe melalui wilayah pesisir, sehingga tak jarang juga masyarakat yang bermatapencaharian sebagai nelayan baik nelayan lautan bebas maupun pantai. Berbicara tentang masyarakat nelayan pastinya pikiran kita tertuju pada masyarakat yang pekerjaannya melaut, baik yang menggunakan sampan, maupun perahu motor. Kapal penangkap ikan merupakan salah satu unsur yang menentukan keberhasilan operasi tangkap ikan selain nelayan dan alat tangkap. Pada pembuatan kapal perikanan, material (bahan baku) merupakan komponen yang sangat penting. terdapat lima jenis material yang sesuai untuk kapal perikanan yaitu kayu, besi, fiberglass, ferrocement, dan alumunium. Perbedaan tipe nelayan maka akan berbeda pula kapal atau perahu yang digunakan, alat tangkap, dan prosesnya.

Kota Lhokseumawe salah satunya daerah yang masih mempertahankan pembuatan kapal nelayan secara tradisional yang hanya berbahan baku kayu seperti, Gampong Ujong Blang, Gampong Ulee Jalan, dan Gampong Pusong Lama. Sehingga penulis melakukan penelitiannya di Kota Lhokseumawe khususnya di tiga gampong tersebut. Namun sekarang ini tidak hanya bahan utama kayu, ada beberapa kapal nelayan yang sudah mengkombinasikan dua bahan baku menjadi satu antara bahan kayu dan fiberglaas, dan ini membuat kapal lebih bagus dan tahan. 
Masyarakat nelayan merupakan salah satu bagian masyarakat Indonesia yang hidup dengan mengelola potensi sumberdaya perikanan. Sebagai suatu masyarakat yang tinggal di kawasan pesisir, mesyarakat nelayan mempunyai karakteristik sosial tersendiri yang berbeda dengan masyarakat yang tinggal di wilayah daratan. Dibeberapa kawasan pesisir yang relativ berkembang pesat, struktuk masyarakatnya bersifat heterogen, memiliki etos kerja yang tinggi, solidaritas sosial yang mendalam (Jurnal Acta Diurna, Volume III, No 3, 2014).

Masyarakat nelayan dapat di pandang sebagai suatu lingkungan hidup dari satu individu atau satu keluarga nelayan. Sebagai sebuah entitas social, masyarakat nelayan memiliki sistem budaya yang tersendiri dan berbeda dengan masyarakat lain yang hidup di daerah penggunungan, lembah atau daratan rendah maupun perkotaan. Masyarakat nelayan secara umum mempunyai pola interaksi yang sangat mendalam, pola interaksi yang dimaksud dapat dilihat dari hubungan kerjasama dalam melaksanakan aktifitas, melaksanakan kontak secara bersama baik antara nelayan dengan nelayan maupun dengan masyarakat lainnya (Jurnal Acta Diurna, volume III, no 3, 2014).

Di Indonesia para nelayan biasanya bermukim di daerah pinggir pantai atau pesisir laut. Jika dilihat dari teknologi peralatan tangkap yang digunakan dapat dibedakan dalam dua kategori yaitu, nelayan modern dan nelayan tradisional. Nelayan kecil merupakan orang yang mata pencahariannya melakukan penangkapan ikan untuk memenuhi kebutuhan hidup sehari-hari dan peralatan penangkapan ikan yang sederhana. Setiap nelayan di Indonesia mempunyai peraturan dan kearifan local tersendiri, seperti halnya nelayan di Aceh yang memiliki peraturan daerah yang disebut Qanun.

Proses kehidupan nelayan ini sangat erat kaitannya secara adat dan budaya serta profesi dengan proses-proses adat lainya, seperti utoh peuraho dan toke bangku. Walaupun kegiatan mereka tidak dapat disebutkan sebagai nelayan, tetapi aktifitas mereka erat kaitannya dengan kehidupan masyarakat nelayan di Aceh. Dalam kehidupan sosial kepada komunitas nelayan yang bermukim di wilayah pesisir terdapat norma-norma tradisi yang hidup dan berkembang hingga kini. 
Kebiasaan tersebut yaitu, tentang adat istiadat yang mengkultur dan menjadi rujukan bagi masyarakat nelayan wilayah pesisir aceh (ego-media.blogspot.com, 2018).

Sebagai sebuah profesi dalam komunitas tertentu, nelayan di Aceh juga memiliki aturan adat lokal yang mengatur berbagai kegiatan nelayan. Aturan tersebut bukan hanya terkait dengan bagaimana tatacara untuk menangkap ikan serta ritual lainnya yang kerap kali menjadi kajian bagi antropologi secara umum. Namun juga aturan tentang bagaimana pembuatan sebuah kapal atau peuraho, aturan memimpin nelayan, dan aturan pemasaran ikan oleh muge dan toke bangku. Oleh karena itu, Peuraho bagi nelayan Aceh adalah jiwa mereka. Para tukang adalah "pencipta" yang menitipkan ruhnya pada perahu-perahu itu. Pembuat peuraho dikenal dengan istilah "utoh". Orang dulu tidak sembarangan memilih utoh untuk membuat kapalnya. Kerajaan Aceh zaman Iskandar Muda (1607-1636), seorang tukang pembuat peuraho termasuk golongan utama dalam masyarakat Aceh zaman dulu. Para tukang ini bertugas membuat kapal nelayan, yang merupakan profesi utama masyarakat pesisir. Para tukang ini pulang yang bertugas membuat kapalkapal perang, yang menjadikan kesultanan Aceh disegani sebagai penguasa Selat Malaka dan pantai barat Sumatera (Lombard, 2006 : 125-128)

Persaingan dalam pembuatan kapal nelayan baik galangan atau industri sangat berat saling menunjukan kualitas dan kuantitas produksinya. Oleh karena itu, peran awak pembuat kapal atau utoh peuraho sangat penting. Melihat kondisi di Kota Lhokseumawe seiring dengan dinamika perubahan lingkungan alam dan lingkungan sosial, ekonomi, politik budaya dan persaingan industri dalam pembuatan kapal modern yang lebih meningkat. Hal inilah yang membuat penulis ingin mengkaji bagaimana pembagian peran utoh peuraho dan praktek pembuatan kapal nelayan secara tradisional di Kecamatan Banda Sakti, Kota Lhokseumawe.

\section{B. Metode Penelitian}

\section{Lokasi dan Pemilihan Informan}

Adapun yang akan menjadi lokasi penelitian ini adalah Kecamatan Banda Sakti, Kota Lhokseumawe. Kota Lhokseumawe yang letak geografisnya berdekatan 
Aceh Anthropological Journal, Vol. 3, No. 2, hlm: 190-201, Oktober 2019

dengan laut khususnya di Kecamatan Banda Sakti yang langsung terhubung dengan garis pantai. Gampong Ujong Blang, Gampong Ulee Jalan, dan Gampong Pusong Lama merupakan tiga dari gampong yang ada di Kecamatan Banda Sakti. Ketiga gampong tersebut terdapat pembuatan kapal, namun ada perbedaan diantara ketiganya yaitu, Gampong Ujong Blang dan Gampong Pusong Lama lebih sering menjadi lokasi membuat kapal berbeda dengan Gampong Ulee jalan tiga tahun terakhir sebagai lokasi pembuatan kapal nelayan. Selain itu, dari hasil pengamatan di lapangan, penulis menetapkan informan sebanyak 12 orang. informan kunci yaitu Utoh peuraho atau ABK sebanyak 6 orang dan kepala tukang 2 orang. Kemudian informan pelengkap Panglima Laot kota Lhokseumawe 1 orang dan pemlik modal (toke) sebanyk 2 orang.

\section{Pendekatan Penelitian}

Secara umum, ada dua pendekatan dalam penelitian ilmu sosial-budaya yaitu, pendekatan kualitatif dan pendekatan kuantitatif. Pada tulisan ini, penulis memilih untuk menggunakan pendekatan kualitatif. Pendekatan tersebut berusaha untuk menggambarkan dan memahami fenomena sosial-budaya yang terjadi dilapangan secara menyeluruh. Etnografi merupakan suatu bangunan pengetahuan yang meliputi teknik penelitian, teori etnografi, dan berbagai macam deskripsi kebudayaan (Spradley, 1997:12). Dalam penelitian etnografi melibatkan langsung pada masyarakat berbagai aktivitas belajar melihat, mendengar, berfikir, dan bertindak dengan berbeda-beda.

Etnografi sebagai representasi adalah suatu perwujudan dari kebudayaan. Etnografi merupakan suatu bangunan pengetahuan yang meliputi teknik penelitian, teori etnografi, dan berbagai macam deskripsi kebudayaan (Spradley, 1997:12). Etnografi merupakan pekerjaan mendeskripsikan suatu kebudayaan. Tujuan utama aktivitas ini adalah memehami suatu pandangan hidup dari sudut pandangan penduduk asli. Sebagaimana dikemukakan oleh Malinowski dalam (Spradley, 1997:3) tujuan etnografi adalah memahami sudut pandang penduduk asli, hubungannya dengan kehidupan, untuk mendapatkan pandangannya mengenai dunianya. Oleh karena itu, etnografi tidak hanya mempelajari masyarakat, tetapi lebih dari itu, etnografi belajar dari masyarakat. 
Penelitian antropologis untuk menghasilkan suatu laporan yang begitu khas, sehingga kemudian istilah etnografi juga digunakan untuk mengacu pada metode penelitian untuk menghasilkan laporan tersebut. Belajar tentang etnografi berarti belajar tentang jantungnya dari ilmu antropologis, khususnya antropologi sosial. Analisis, dalam bentuk yang bagaimana pun melibatkan suatu cara berfikir. Analisis merujuk pada pengujian sistematis terhadap sesuatu untuk menentukan bagianbagiannya, hubungan di antara bagian-bagian, serta hubungan bagian-bagian itu dengan keseluruhannya (Spradley, 1997:117).

Cara baik belajar etnografi adalah dengan melakukannya. Asumsi ini mempengaruhi pandangan bagian kedua. Masing- masing berisi elemen-elemen yaitu, tujuan pernyataan singkat mengenai tujuan yang dipelajari dalam tiap-tiap tahapan tertentu dalam proses etnografi. Konsep pembahasan mengenai konsepkonsep dasar yang dilakukan untuk mencapai tujuan yang dipelajari dalam masingmasing tahapan tertentu. (Spradley, 1997:56).

Karakteristik utama dari metode ini adalah sifat analisisnya yang mendalam, kualitatif, dan holistic-integratif. Selain itu teknik utama etnografi adalah observasi partisipasi yang dilakukan dalam waktu yang relative lama, serta wawancara mendalam (depth interview) yang dilakikan secara terbuka. Oleh sebab itu, seorang etnografer tidak hanya melakukan studi pada tataran atas, namun ia benar-benar memahami pikiran, perilaku, dan kebudayaan sebuah masyarakat (Jurnal SMaRT, volume 01, nomor 02, Desember 2015:259).

\section{Pembahasan}

\section{Sejarah Dan Perkembangan Utoh peuraho}

Aktifitas propesi nelayan, dalam setiap komunitas nelayan di Aceh bisa di pastikan memiliki aturan adat lokal yang mengatur berbagai kegiatan neyan itu sendiri. Aturan adat mulai dari pembuatan peuraho, aturan memimpin nelayan, dan aturan pemasaran ikan oleh muge dan toke bangku. Peuraho bagi nelayan Aceh adalah jiwa mereka. Para tukang adalah "pencipta” yang menitipkan ruhnya pada perahu-perahu itu. Pembuat peuraho dikenal dengan istilah "utoh". Pada masa 
lampau dalam membuat kapal tidak sembarangan memilih utoh untuk membuat kapalnya.

Menurut Denys Lombard dalam buku Kerajaan Aceh zaman Iskandar Muda (1607-1636), seorang tukang pembuat peuraho termasuk golongan utama dalam masyarakat Aceh zaman dulu. Para tukang ini bertugas membuat kapal nelayan, yang merupakan profesi utama masyarakat pesisir. Para tukang ini pula yang bertugas membuat kapal-kapal perang, yang menjadikan kesultanan Aceh disegani sebagai penguasa Selat Malaka dan pantai barat Sumatera. Awal mulanya pembuatan kapal, pada zaman dahulu Sultan Iskandar Muda menemukan kayu yang terdampar di pantai, kemudian Ia membawa kayu tersebut kepada utoh sebagai bahan pembuatan kapal perang. Sehingga kapal tersebut terkenal dengan namanya Cakra Donya “Teror Dunia” (Lombard, 2014 : 125-128).

Pembuatan kapal nelayan tradisional semakin berkembang. Hal ini dapat dilihat semakin meningkat pesanan baik yang dioperasikan dari Kota Lhokseumawe maupun luar daerah. Pembuatan kapal nelayan dari zaman dulu hingga sekarang ini masih tradisonal walaupun beberapa alat yang digunakan pembuatan kapal tidak tradisional. Sama halnya dengan utoh peuraho yang berkembang. Pembuatan kapal nelayan saat ini tidak hanya melibatkan utoh dari Kota Lhokseumawe namun juga utoh lintas provinsi. Pembuatan kapal nelayan di Kecamatan Banda Sakti adalah utoh peuraho yang berasal dari luar Kota Lhokseumawe. Selain itu, lokasi pembuatan kapal nelayan di Kota Lhokseumawe di Gampong Ujong Blang, Gampong Pusong Lama, dan Gampong Jambo Timu. Pembuatan kapal nelayan lokasi tersebut sudah ada sejak dulu dan tidak pernah berubah seperti seakarang ini. Namun, lokasi pembuatan kapal nelayan yang eksis dan jenis kapalnya yang besar hanya di Gampong Ujong Blang dan Gampong Pusong Lama yang berada di Kecamatan Banda Sakti. Penentuan lokasi juga disepakati antara toke dengan kepala tukang. Sehingga pembuatan kapal nelayan tradisional sekarang ini tidak hanya kedua gampong tersebut. Namun, terdapat lokasi baru, yaitu di Gampong Ulee Jalan Kecamatan Banda Sakti.

Utoh peuraho yang ada di Aceh khususnya Kota Lhokseumawe masih mempertahankan proses pembuatan kapal nelayan bahan baku kayu dari zamannya 
Sultan Iskandar Muda hingga saat ini. Namun, ada beberapa perubahan bahan baku dan alat-alat pembuatan kapal. Untuk bahan bakunya jika dulu dalam pembuatannya menggunaan kayu sebagai bahan utamanya, tetapi sekarang ini bahan yang digunakan kayu kombinasi fiberglass dan untuk alat yang digunakan sudah mengalami perubahan lebih modern. Sehingga membantu pekerjaan para utoh lebih cepat pengerjaannya, dimana yang dulu membutuhkan waktu yang lama berbeda dengan sekarang yang lebih cepat mengefesiensi waktu targantung dari ukuran dan kendala dalam pembuatan kapal.

\section{Pola Pembagian Peran Utoh Peuraho dalam Pembuatan Kapal Nelayan}

Laut merupakan ajang untuk mencari hasil sumber daya alam bagi masyarakat nelayan. Aceh mempunyai posisi yang strategis. Selain berhimpit antara Selat Malaka dan Samudera Hindia juga kawasan, juga sebagai zona perekonomian antar daerah hingga macanegara. Berbagai jenis kapal melitas di laut Aceh baik kapal nelayan maupun kapal komersial. Pengaruh kebudayaan dari satu daerah ke daerah lain tidak dapat dilepaskan dari peranan perahu dalam proses penyebaran kebudayaan. Pembuatan kapal sudah berlangsung dari masa Kerajaan Aceh. Peran utoh peuraho zaman dahulu dengan sekarang ini masih sama. Namun yang membedakan hanya fungsi dari perahu atau kapal yang dibuat.

Kelompok kerja dalam pembuatan kapal nelayan terdiri dari toke, kepala utoh peuraho, dan awak utoh peuraho. Stratifikasi sosial yang menonjol pada pembuatan kapal nelayan adalah berdasarkan peran dan fungsi dari masing-masing, serta keahlian dan keterampilan masing-masing dalam bekerja. Di bawah ini akan dijelaskan bagaimana peran dan fungsi kelompok dalam pembuatan kapal nelayan di Kecamatan Banda Sakti Kota Lhokseumawe. Terdapat tiga tingkatan peran pekerjaan pada pembuatan kapal nelayan, yaitu sebagai berikut :

a. Pemilik modal (Toke)

Pemilik modal adalah pemimpin dalam pola pembagian peran pada pembuatan kapal nelayan. walaupun posisinya berada yang tertinggi tetapi tidak ikut terlibat dalam pembuatan kapal nelayan, kewenangannya hanya sebagai toke saja. hal ini terjadi di Gampong Ulee Jalan dan Pusong Lama, dimana seorang toke 
yang tidak terlibat dalam pembuatan kapal Nelayan. Namun, berbeda dengan Gampong Ujong Blang sebagai toke yang terlibat langsung dalam pembuatan kapal sebagai utoh peuraho.

Adapun peran dalam hal ini tugas-tugas seorang toke, yaitu :

- Melakukan negoisasi pemesanan kapal pada kepala utoh.

- Mempersiapkan modal / dana tambahan, apabila terjadi pengeluaran tak terduga

- Melakukan perizinan pembangunan

- Penyediaan dan pembelian bahan baku

- Menentukan utoh peuraho

- Mengelola ketersediaan bahan baku mulai dari awal pembuatan sampai selesainya kapal.

Pada masa dulu dalam pembuatan kapal nelayan di Aceh, penyediaan bahan baku seorang utoh peuraho harus memilih sendiri dari hutan yang akan digunakan untuk bahan pembuat kapal. Jenis dan kualitas bahan baku yang sesuai dengan bentuk kapal yang akan digunakan. Setelah pemilihan bahan yang terbaik, pohon tersebut boleh ditebang. Namun sekarang ini bahan baku disediakan oleh toke yang telah ditentukan jenisnya.

Adapun kayu yang diperoleh dari lahan atau hutan yang ada di sekitaran Aceh Utara, seperti daerah Sawang, Buloh Blang Ara, dan berbagai daerah lainnya yang di distribusikan langsung dari pengepul kayu. Jika dana dan pemasokan kayu terhambat maka proses pembuatan kapal nelayan tidak sesuai dengan target. Selain itu, selama dalam pembuatan kapal berlangsung, ia juga mengawasi pekerjaan para utoh. Pengawasan ini dilakukan setiap hari, perminggu, ataupun perbulan hingga selesainya kapal.

b. Kepala Tukang (Kepala Utoh)

Kepala tukang atau kepala utoh yang memimpin beberapa orang yang disebut utoh peuraho. Status seorang kepala utoh ini diperoleh karena keahlian khusus seperti teknis pada pembuatan kapal dan mendapatkan pemesanan. Syarat utama seseorang untuk menjadi kepala utoh adalah memiliki kemampuan teknis 
dan keterampilan pada pembuatan kapal. Dengan kemampuan tersebut dapat menjadi dasar pelaksanaan proses pembuatan kapal. Mulai dari kepercayaan toke untuk pemesanan kapal, mendesain kapal sesuai dengan pesanan, negoisasi mengenai upah, mencari utoh peuraho, penentuan bahan baku, dan lokasi pembuatan.

Selain itu, kepala utoh juga memiliki tanggung jawab yang besar terhadap utoh peuraho. Pertama, memiliki tanggung jawab utama dalam pembuatan kapal dari pemesan kapal, kedua adalah ilmu yang dimiliki oleh kepala utoh juga dapat menjadi pengetahun bagi utoh peuraho selama bekerja.

\section{c. Awak Pembuat Kapal (Utoh Peuraho)}

Awak pembuat kapal atau utoh peuraho merupakan seorang pekerja dalam pembuatan kapal yang diperintahkan dan dalam pengawasan kepala utoh. Utoh peuraho berada pada posisi ketiga setelah toke dan kepala utoh. Pada proses pembuatan kapal, utoh peuraho memiliki upah yang paling sedikit dibandingkan dengan kepala utoh.

Selanjutnya peran utoh peuraho dalam pembuatan kapal nelayan, yaitu membuat kapal nelayan yang telah di desain oleh kepala utoh. Mulai pemotongan kayu, pemasangan lunas, pemasangan linggi haluan (ulee krueeh), pemasangan linggi buritan (tiang saf), pemasangan lambung kapal, pemasangan gading-gading (geunadeng), pemasangan galar kim dan galar balok (naga), pemasangan leger, pemasangan papan dep (aneuk dep) pembuatan ruang muat dan ruang mesin, pembuatan bangunan atas, pemakalan dan pendempulan, dan terakhir pemasangan seng atau fiberglass pada kapal. Selain itu, utoh peuraho juga memiliki peran dalam mencari utoh lain yang ingin dipekerjakan dengan izin kepala utoh.

Pada pembangunan kapal nelayan berbahan kayu secara keseluruhan tidak ada pembagian pekerjaan antar utoh peuraho. Namun, pembagian peran pekerjaan hanya terdapat pada pemasangan fiberglass. dalam pembuatan kapal nelayan di Gampong Ujong Blang tidak ada pembagian peran dalam bekerja. Dimana pembuatan kapal bekerja sama tidak ada perbedaannya. Jika utoh memerlukan bantuan maka pekerjaan tersebut akan dikerjakan bersama. Berbeda halnya 
Aceh Anthropological Journal, Vol. 3, No. 2, hlm: 190-201, Oktober 2019

pembagian peran ini terjadi di Gampong Ulee Jalan dan Pusong Baru, dimana kedua gampong tersebuat merupakan kapal nelayan yang berlapis dengan fiberglass.

Pembagian peran ini terjadi karena kurangnya pengetahuan utoh peuraho yang berasal dari daerah Aceh tentang pemasangan fiberglass secara manual. Sehingga terjadilah pembagian peran. Pemasangan fiberglass oleh utoh peuraho yang berasal dari pulau Jawa.Oleh karena itu, perlu sudikiranya para utoh peuraho yang ada di Kota Lhokseumawe untuk memperluas kemampuan dan keterampilan tentang hal-hal baru pembuatan kapal nelayan. Tetapi, tetap menjaga kepiawaian ciri khas daerah. Sehingga pembuatan kapal nelayan semakin berkembang dan menjadi identitas masyarakat nelayan

\section{Kesimpulan}

Berdasarkan tujuan penelitian yang ingin dicapai dari hasil pembahasan mengenai kajian pola pembagian peran utoh peuraho di Kecamatan Banda Sakti, Kota Lhokseumawe dapat disimpulkan sebagai berikut :

Pola pembagian peran utoh peuraho terbentuk saling berkaitan satu dengan lainnya. Dengan status kedudukan tersebut terbagi menjadi tiga, yaitu : toke (pemilik kapal), kepala utoh (kepala tukang), dan utoh peuraho (awak pembuat kapal). Fungsi dari peran yang dimiliki oleh toke, kepala utoh, dan utoh peuraho berbeda-beda dan saling kerterkaitan satu sama lainnya. Dimana toke merupakan yang menyediakan modal dalam pembuatan kapal. Kepala utoh merupakan seseorang yang mendesain kapal dan mengatur pekerjaan utoh peuraho. Sedangkan utoh peuraho merupakan seseorang yang menerima perintah dari kepala utoh pada pembuatan kapal. 
Aceh Anthropological Journal, Vol. 3, No. 2, hlm: 190-201, Oktober 2019

\section{Daftar Pustaka}

Annisha. (2017). Mari menjelajahi Kawasan Pantai Ujong Blang, Editor: Ibrahim dan Fatchur Rohman.

Fanesa, Fargomeli. 2014. Interaksi Kelompok Nelayan dalam Meningkatkan Taraf Hidup Di Desa Tewil Kecamatan Maba Halmahera Timur. jurnal Acta Diuma, Volume III, No 3.

https://geomedia.blogspot.com/2018/04/hukum-adaat-laut-aceh-panglima laot.html?m-1

Koeswinarto. 2015. Memahami Etnografi Ala Spradley. jurnal SMaRT, Volume 01, Nomor 02.

Lombard, Denys. (2014). Kerajaan Aceh Zaman Sultan Iskandar Muda (1607-1636). Jakarta: KPG (Kepustakaan Populer Gramedia).

Spradley, James.P. (1997). Metode Etnografi. Yogya: Pt. Tiara Wacana. 